\title{
Rosyjscy emigranci w miniaturach satyrycznych Arkadija Awierczenki
}

\author{
Russian emigrants in satirical miniatures \\ by Arkady Averchenko
}

\begin{abstract}
The transformations in Russian satirical literature conditioned by the difficult emigration situation were reflected in the works of Arkady Averchenko, one of the most significant satirists of pre-revolutionary Russia. In his short stories created in exile, the writer showed the problems and dilemmas that his fellow-countrymen had to face abroad, mainly in Constantinople and Prague. The feeling of homelessness, loneliness and uprooting that accompanied the emigrants constantly intensified the need for self-identification in a foreign culture, which was demonstrated in manifesting their national distinctiveness, confronting new customs and idealizing the Russian past. By immortalizing the mood, spiritual life and living conditions as well as a specific metamorphosis of Russian emigrants, Averchenko did not forget about their vices. Therefore, the short stories of the emigration period, in which the writer willingly combined elements of comedy and tragedy, were saturated with self-irony, pain and bitter reflection, skillfully hidden under the mask of humour and satire.
\end{abstract}

Keywords: Arkady Averchenko, first wave of emigration, refugee, humour, satire

Nel Bielniak, Uniwersytet Zielonogórski, Zielona Góra - Polska,n.bielniak@in.uz.zgora.pl, ORCID ID: https://orcid.org/0000-0002-5101-1629

Arkadij Awierczenko był jednym z najbardziej znaczących satyryków przedrewolucyjnej Rosji, czego odzwierciedleniem są m.in. takie określenia jak król śmiechu czy rosyjski Mark Twain. I choć był on także dramaturgiem i krytykiem teatralnym, zasłynął głównie jako autor humoresek i opowiadań satyrycznych, które z równą przyjemnością czytali zwykli obywatele, jak i sam Mikołaj II. Jeden z pierwszych zbiorów jego opowiadań, zatytułowany Веселье устрицы. Юмористические рассказы, opublikowany w 1910 roku, doczekał się ponad dwudziestu wznowień, co bez wątpienia świadczyło o niezwykłej poczytności tego pisarza (zob. Ikitân 55; Spiridonova, źródło elektroniczne; Bondareva 14; Kasack 45). Tom ten był wyjątkowy także $\mathrm{z}$ tego powodu, że składał się wyłącznie z utworów wcześniej niepublikowanych na łamach powstałego w 1908 
roku czasopisma „Satirikon” („Сатирикон”), którego redaktorem i stałym autorem był Awierczenko, o czym czytelnicy tego pisma mogli przeczytać w notce zamieszczonej 3 lipca 1910 roku w numerze 27 na stronie 11 (Nikolaev 21). Ten „tygodnik satyry i humoru” na rosyjskim rynku wydawniczym wyróżniał się wysokim poziomem. Zachęcało to do współpracy utalentowanych twórców, uprawiających różne gatunki i formy satyryczne, co przyczyniło się do odnowienia rodzimej tradycji satyrycznej. Sam redaktor naczelny tak oceniał w 1920 roku działalność „satirikonców”:

Моими товарищами по работе, ближайшими сотрудниками были: Тэффи, Арк. Бухов, Саша Чёрный, художники Радаков, Юнгер, изумительный художник-график и живописец Александр Яковлев, темпераментный, яркий, неожиданный, как ракета, карикатурист РеМи - с такой блестящей гвардией можно было завоевать не только Россию, но и весь мир. Никто иной, как мои товарищи сатириконцы, подняли упавший, скитавшийся до того по задворкам портерных [русский] юмор - на недосягаемую высоту! (Milenko 2018b: 58)

Większość współpracowników czasopisma funkcjonującego od 1913 roku pod nazwą „Nowyj Satirikon” („Новый Сатирикон”), w tym także część wymienionych wyżej, zdecydowała się po jego zamknięciu przez władze bolszewickie w sierpniu 1918 roku na opuszczenie ojczyzny. Dzięki temu rosyjska literatura satyryczna zaistniała na emigracji jako zjawisko całościowe, choć jednocześnie znacznie się przeobraziła. Naturalną koleją rzeczy tragiczne doświadczenia rewolucji i wojny domowej odcisnęły na niej swoje piętno. Dlatego też w pierwszych latach po przewrocie bolszewickim zdecydowanie nasilił się w niej pierwiastek publicystyczny, a miejsce czystego humoru zajęła ostra, aktualna satyra polityczna skierowana przeciwko nowemu reżimowi. Z czasem jednak tendencja ta osłabła, pisarze próbowali bowiem wskrzesić dawny dobroduszny humor. Coraz częściej także w utworach byłych satirikonców zaczęły pojawiać się nostalgiczne motywy (Averin, Karpov, Titarenko 273).

Podobne zmiany wyraźnie zaznaczyły się w także w twórczości Awierczenki, który początkowo udał się na zajęte przez białych Południe, a jesienią 1920 roku wraz z ewakuującymi się wojskami generała Piotra Wrangla przedostał się do Konstantynopola, gdzie spędził około półtora roku. Z kolei w czerwcu 1922 roku przybył do Pragi i mieszkał tam aż do śmierci w marcu 1925 roku. I choć czas spędzony przez humorystę na uchodźstwie był stosunkowo krótki, zdołał on nie tylko odwiedzić Bułgarię, Królestwo Serbów, Chorwatów i Słoweńców, Austrię, Republikę Weimarską, Litwę, Łotwę, Estonię, Polskę, Wolne Miasto Gdańsk i Rumunię (Milenko 2018a: 78), lecz także wydać liczne zbiory opowiadań i pamfletów (m.in. Нечистая сила, 1920; Дюжина ножей в спину револючии, 1921; Кипящий котел, 1922; Дети, 1922; Отдых на крапиве, 1924; Рассказы циника, 1925). Zdaniem Mikołaja Kruka w utworach powstałych 
[...] po roku 1917 można zaobserwować stopniową, ale wyraźnie rysująca się ewolucję od śmiechoterapii, mającej być ratunkiem dla pogrążonych w pesymizmie, poprzez śmiech-zapomnienie, śmiech przez łzy, aż do kpiny, ironii i szyderstwa. Niewinny humor ustępuje miejsca najpierw łagodnej ironii, a później pamfletowej złośliwości (Kruk 133).

Awierczenko, jako nieprzejednany wróg nowej władzy, wiele utworów poświęcił zarówno tematyce antysowieckiej, jak i wyśmiewaniu absurdów „,sowdepowskiej”"1 rzeczywistości. Takie wątki można odnaleźć m.in. w tomie Смешное в страшном opublikowanym w 1923 roku w Berlinie. Pisarz, w pełni świadomy rozpaczliwej sytuacji panującej w ojczyźnie, zastanawia się, czy w takich okropnych czasach jest jeszcze miejsce na śmiech i humor. Dlatego też zbiorek otwiera Извинение автора, który zapytuje:

Не преступление ли - отыскивать смешное в страшном?

Не кощунство ли - весело улыбаться там, где следовало бы рвать волосы, посыпать пеплом главу, бия себя в грудь, и, опустившись на колени возле вырытой могилы, долго неутешно рыдать? (Averčenko 2015: 5)

Awierczenko wierzy jednak w Rosję, w jej niezniszczalność i odrodzenie, jak też w terapeutyczną moc śmiechu, dlatego konstatuje:

Значит, смеяться можно.

Больше того, - смеяться должно. Потому что у нас один выбор: или пойти с тоски повеситься на крючке от украденной иконы, или - весело, рассыпчато рассмеяться (Averčenko 2015: 5-6).

Wśród zamieszczonych w tym tomie „szkiców nowej obyczajowości” („,очерки нового быта"), by użyć określenia autora, można również odnaleźć opowiadanie pod znamiennym tytułem Тоска по родине, w którym poruszony został jakże charakterystyczny dla twórców pierwszej fali emigracji motyw tęsknoty za opuszczoną Rosją, by przywołać tylko takie tytuły, jak Тоска (1920) і Ностальгия (1920) Nadieżdy Teffi, Родина (1924) Aleksandra Kuprina czy Тоска по родине! Давно... (1934) Mariny Cwietajewej.

Warto tu zaznaczyć, że Awierczenko, którego Ludmiła Ikitian postrzega jako „[х]удожника сильной комической жилки [...], автора каламбуров, ироничных подтекстов, парадоксов, фарсовых ситуаций, остроумных диалогов и пр." (Ikitân 55), w utworach powstałych na emigracji nierzadko przeplata elementy komiczne z tragicznymi, co skądinąd było wyróżnikiem satyrycznej literatury emigracyjnej w ogóle (Mânovska 221-222). Stąd też w analizowanym opowiadaniu zbudowanym z dialogów pełnych niespójności i nieoczekiwanych

${ }^{1}$ Sowdepia (od akronimu oznaczającego sowiecki departament) to pogardliwe określenie, którym emigranci nazywali sowiecką Rosję (Figes 528). 
zwrotów myśli, co daje komiczny efekt, jest też miejsce dla refleksji o niezwykle trudnym położeniu emigrantów, dobrze przecież znanym samemu autorowi. Dzięki temu spomiędzy wierszy wyłania się obraz rosyjskich uchodźców w Konstantynopolu, zagubionych i osamotnionych w obcym otoczeniu kulturowym. Dlatego też dodają sobie otuchy opowieściami o dawnych, lepszych czasach, które jednocześnie konfrontują z nowymi, nieprzyjaznymi realiami. Wspominkom sprzyja świąteczny czas Bożego Narodzenia, który uchodźcy spędzają stłoczeni w wieloosobowym pokoju w domu noclegowym. Ich niechęć budzi zwłaszcza dżdżysta pogoda: „Гнилая константинопольская погода. С неба падают редкие капли скудного дождя, будто кто-то сверху брызгает облысевшим кропилом" (Averčenko 2015: 76). Diametralnie różni się ona bowiem od aury zazwyczaj panującej w tym okresie w Rosji. Dlatego też mieszkańcy noclegowni początkowo przywołują wizje zasypanej śniegiem Moskwy, silnych mrozów, skrzypiących sań i dzwoneczków przy końskiej uprzęży. Później zaś, przekonani o wyższości wszystkiego, co rosyjskie, wspominają m.in. czyste, błękitne niebo i cudowne rosyjskie zapachy. Oczywiście Awierczenko w typowy dla siebie sposób ukazuje predylekcję rosyjskiej diaspory do powracania „do przeszłości, której nie było - do przeszłości, która nigdy nie była ani tak dobra, ani tak «rosyjska», jak ją wspominali emigranci" (Figes 534). Prozaik wprowadza bowiem do wypowiedzi bohaterów zmiany naruszające logiczny bieg myśli, które poprzez swą kuriozalność nie tylko zwracają uwagę czytelnika, lecz także pozwalają spojrzeć na zagadnienie z nowej perspektywy (Ikitân 62):

- У нас в Москве и сирень пахнет лучше, чем где. Я раз в Петровском парке так-то вот под сиренью сидел, вдыхал это самое... Вдруг двое выскочили: „Скидывай, говорят, пиджак"... Чудесные ребята! Я бы с ними сейчас даже пива в Трехгорном выпил. Замечательные были времена.

- Что ж, отдал?

- Чего?

- А пиджак!

- Как же не отдать, если они враз за горло, тут и штаны отдашь! Ей-богу, доведись как теперь - то я бы сейчас все время под сиренью сидел и пиджаки им отдавал (Averčenko 2015: 78-79).

Konstantynopolskie doświadczenia i obserwacje posłużyły pisarzowi także za kanwę opowiadań zebranych w tomie Записки Простодушного opublikowanym w 1921 roku w tureckiej metropolii. Po dwóch latach w Berlinie ukazało się rozszerzone wydanie. Zmodyfikowany został tytuł, który brzmiał teraz Записки Простодушного. „Я в Европе”. Туриия, Чехо-Словакия. Ponadto dodana została druga część, która zawierała miniatury wyrosłe z praskich przeżyć autora, a część pierwsza została wzbogacona o trzy nowe opowiadania: Константинопольские греки, Утопленники oraz Дела. W sumie w zbiorze znalazło się 
trzydzieści jeden miniatur z życia rosyjskich uchodźców, przesyconych autoironią, bólem i smutkiem, zręcznie ukrytymi pod maską humoru i satyry. Na to, że w centrum zainteresowania pisarza znalazły się bolączki emigracyjnej egzystencji, wskazywał podtytuł zamieszczony w pierwszym wydaniu: $О$ намей жизни, терзаниях, приключениях, о том, как мы падали, подымались и вновь падали, о нашей безжалостной борьбе и о тихих радостях (Averčenko 2018: 2).

Z kolei nowy, „egocentryczny”, jak go określa Olga Letka-Spychała, podtytuł Я в Европе uwydatnia nader istotny problem samoidentyfikacji pisarza i pierwszoosobowego narratora $\mathrm{w}$ obcej kulturze, przejawiający się m.in. w manifestowaniu odrębności narodowej (zob. Letka-Spychała 50; Želtova 207). Zachowanie tytułowego Prostodusznego rzeczywiście cechuje skłonność do postrzegania otaczającego świata przez pryzmat opozycji swój - obcy, przybierającej formę stereotypów narodowych i etnicznych o silnym ładunku emocjonalnym. Poczucie tożsamości narodowej jest bowiem ściśle powiązane $\mathrm{z}$ autostereotypem i heterostereotypami. Autostereotyp jest obrazem własnym grupy, który powstaje na skutek sprowadzania rozmaitych przejawów życia narodowego do wspólnego mianownika. Bazuje na uogólnieniach podobieństw i cech wspólnych, a przy tym nie eksponuje odpowiednio różnic i podziałów istniejących wewnątrz wspólnoty narodowej. Na zasadzie typizacji i generalizacji kształtują się także pod postacią heterostereotypów obrazy innych wspólnot narodowych (Błuszkowski 16).

Awierczenko w poszukiwaniu źródeł rosyjskiego charakteru narodowego odwołuje się w przedmowie [Предисловие Простодуиного (Как я уехал)] do ambiwalentnego obrazu folklorystycznego Iwana Głupiego, paradoksalnie łączącego głupotę i mądrość. Roman Szubin (nawiązujący do teorii Władimira Kolesowa) zauważa, że „русский дурак («специфическое русское понятие») «не дурак вовсе, поскольку на самом деле он - инверсия мудрецу», «дурак - это умный наоборот», поэтому стоит говорить об особом русском уме, а не о глупости дурака, «баловня трех С.» - счастья, судьбы и свободы” (Šubin 444). I tacy właśnie, w przekonaniu pisarza, byli na początku tułaczej wędrówki Prostoduszny i jego rodacy: naiwni, ufni, nieco może idealistyczni i beztroscy. Jednakże z czasem, pod wpływem niekończących się rozczarowań, porażek i ciosów od życia rosyjscy emigranci przeobrażali się, przystosowywali do trudnych warunków, stawali się twardsi i sprytniejsi, ale czy były to zmiany na lepsze? - zastanawia się narrator w zakończeniu (Заключение) pierwszej części tomu:

Во всяком случае - умер Простодушный...

Доконал Константинополь русского Простодушного.

Целый ряд лет еще промелькнет перед нами... Но все эти годы уже будут обвеяны мудростью, хитростью и, может быть, - жестокостью.

Выковали из нас - благодушных, мягких, ласковых дураков - прочное железное изделие (Averčenko 2018: 122). 
W podziale tomu na „cykl konstantynopolski” i „,cykl czechosłowacki” kryje się także, jak się zdaje, stosunek Awierczenki do obu tych miast. Turecka metropolia, bardziej odległa kulturowo, była mniej przyjaznym miejscem dla emigrantów niż opisana w drugiej części Praga. Nastawienie pisarza znalazło wyraz w krótkich, acz treściwych opisach tych aglomeracji. W opowiadaniu Благородная девушка narrator konstatuje: „Вот тебе и Константинополь! А говорят город продажных женщин и торгующих женщинами мужчин” (Averčenko 2018: 68). Natomiast nieco dalej w tym samym utworze czytamy: „Приветствую тебя, старый изможденный развратный мошенник - Константинополь!" (Averčenko 2018: 72). Z kolei w miniaturze zatytułowanej po prostu Прага pojawia się deskrypcja czechosłowackiej stolicy o zdecydowanie innym zabarwieniu: „О, прекрасная старуха, милая сердцу каждого художника, - думал я, - сколько веков копила ты свои каменные сокровища и как ты ревниво бережешь их, подобно скупому рыцарю..." (Averčenko 2018: 123). Na takie przyjazne nastawienie humorysty wpływ miała zapewne życzliwa polityka czechosłowackich władz, które nie tylko hojnie wspierały rosyjskich emigrantów, np. przyznając stypendia rosyjskim studentom, lecz także zachęcały wybitnych ludzi nauki, pisarzy, pedagogów i myślicieli do zamieszkania w ich kraju (zob. Figes 526-527; Tolstoj). Nie bez znaczenia były także osobiste doświadczenia Awierczenki, na którego po przyjeździe do Pragi na peronie czekali liczni wielbiciele oraz przedstawiciele miejscowej prasy (Egorova 138).

Natomiast źródła mniej przychylnej oceny tureckiej metropolii przez rosyjskiego twórcę kryły się najprawdopodobniej w innych okolicznościach. Turcja nie zapraszała bowiem na podobieństwo Czechosłowacji jedynie wybranych grup spośród uchodźców, lecz ze względu na swoje położenie geograficzne stała się głównym miejscem pierwszego schronienia rosyjskich emigrantów. W wyniku pięciu masowych ewakuacji z byłego Imperium Rosyjskiego na początku lat 20. XX wieku na terytorium Turcji znalazło się ok. 250 tysięcy uciekinierów: wojskowych i cywilów. I choć ich liczba stale się zmieniała, ponieważ zamożniejsi w krótkim czasie otrzymywali wizy i wyjeżdżali do Europy, to w Konstantynopolu wciąż pozostawały rzesze przede wszystkim słabo sytuowanych uchodźców. W konsekwencji miasto było przeludnione, brakowało pracy, mieszkań i żywności, ceny szalały (w 1921 roku ceny na podstawowe produkty spożywcze wzrosły o $1400 \% \mathrm{w}$ porównaniu z przedwojennymi), pojawiło się także zagrożenie masowymi epidemiami (Škarovskij; Sabennikova 237-243; Ippolitov, Karpenko, Pivovar).

Wspomniane problemy wyraźnie zaznaczyły się w „осколках константинопольской жизни", jak sam Awierczenko nazywa miniatury z pierwszej części omawianego tomu. Uchodźcom po zejściu na brzeg Galaty od razu rzucały się w oczy nieprzebrane thumy rodaków, co humorysta utrwalił w zabawnym dialogu w opowiadaniu zatytułowanym Первый день в Константинополе: 
На Пере среди грохота и гвалта меня остановила какая-то божья старушка - столь уже уместная тут, как цветочек незабудки в пасти аллигатора.

- Что вам, бабушка?

- Голубчик мой, а где ж тут турки?

- Которые?

- Да ведь это, чай, Турция.

- Чай, она.

- А чего ж турка ни одного нет? (Averčenko 2018: 13)

Nieprzypadkowo pojawiła się tu także nazwa dzielnicy Pera, gdzie umiejscowiona jest akcja wielu miniatur Awierczenki. Tam znajdowała się bowiem ambasada Imperium Rosyjskiego, a przy niej działały m.in. kwatera generała Wrangla, szpital oraz Rosyjski Czerwony Krzyż. W rezultacie Pera stała się centrum emigracyjnego życia:

Если кто желал что-нибудь узнать, навести справку, разыскать знакомого, найти или предложить работу, - все шли сюда со всех концов города. Обычным местом сбора был посольский двор, своего рода беспроволочный радио-телеграф и клуб. Здесь получались всевозможные сведения, невероятные слухи и распространялись отсюда с неправдоподобной быстротой по всему городу и „беженскому миру” (Ippolitov, Karpenko, Pivovar).

Ponura emigracyjna codzienność w tureckiej stolicy została przez pisarza spetryfikowana m.in. w opowiadaniu Язык богов, które rozpoczyna się od charakterystyki warunków bytowych rosyjskiego uchodźcy:

Маленькая, грязная комнатка, с гримасой бешенства сдаваемая маленькой грязной гречанкой одному моему беззаботному знакомому.

Он слишком горд, чтобы признать отчаянное положение своих дел, но, зайдя к нему сегодня, я сразу увидал все признаки: вымытую собственными руками рубашку, сушившуюся на портрете Венизелоса, тарелку, на которой лежал огрызок ужасающей жареной печенки, с обломком семита, - отложенные в качестве ужина, грязная закопченная керосинка, с какой-то застывшей размазней в кастрюле (Averčenko 2018: 98).

Natomiast problem głodu, braku pracy i pieniędzy prześladujący białogwardzistów, którzy za kawałek chleba gotowi byli wykonać każde zlecenie, pojawił się niejako na marginesie w utworze Оккультные тайны Востока, którego bohaterem jest kontuzjowany pod Pierwozwanowką były kapitan pułku Markowa. Cywilni emigranci także przyjmowali każdą pracę, nawet tymczasową i najcięższą, za bardzo skromne wynagrodzenie. Byli arystokraci, generałowie, profesorowie, wybitni twórcy i aktorzy po utracie elitarnej pozycji teraz pracowali jako kelnerzy czy portierzy. Tę nową dla nich i niezwykle trudną sytuację prozaik zobrazował w następujących miniaturach: Русские женщины в Константинополе, Русское искусство, О гробах, тараканах и пустых внутри бабах оraz Еще гроб. Z kolei ci bardziej przedsiębiorczy, mający odpowiednie środki i wierzący w sukces, 
otwierali lokale rozrywkowe: restauracje, kawiarnie, kluby lub zakładali gazety, co jednak, jak to zostało przedstawione w miniaturach Аргонавты и золотое руно oraz Утопленники, często kończyło się klęską.

Wrażenia wyniesione przez rosyjskiego humorystę z Konstantynopola i Pragi zaważyły, jak się zdaje, na jego wyobrażeniach o innych grupach narodowych. Heterostereotypy mieszkających w Konstantynopolu Turków i Greków, które można odnaleźć głównie w opowiadaniach Еще гроб і Константинопольские греки, uwypuklają przede wszystkim negatywne cechy przedstawicieli tych nacji. Grecy zostali zobrazowani jako skąpi ciułacze i wyrachowani oszuści wykorzystujący trudną sytuację Rosjan, Turcy zaś jako hałaśliwi handlarze. Takie właśnie postrzeganie, zdawać by się mogło, że od niechcenia, a w istocie bardzo celnie, uchwycił prozaik w pierwszym z wymienionych utworów:

В такие минуты любо беспричинно бродить по улицам, обращая умиленное внимание на всякий пустяк, попадающий в поле зрения: на турка, исступленно выкрикивающего свой товар; на деловитого грека, бегущего из харчевни с тарелочкой, на которой - горсточка вареного риса, возглавленного крохотным кусочком баранины; на фотографическую витрину с усатыми, толстоногими гречанками [...] (Averčenko 2018: 62).

Zdecydowanie inaczej sportretował Awierczenko mieszkańców Pragi w opowiadaniach Прага, Чехи, Кнедлики oraz Самый страшный притон Праги. Jego zdaniem, są to ludzie tak spokojni, kulturalni, poukładani i zrównoważeni, że nawet stałych bywalców najgorszej spelunki w stolicy wyróżnia uprzejmość, oczytanie i chęć niesienia pomocy obcym. Choć i w tym idealnym obrazie znalazły się rysy. Ad exemplum wspomnianą miniaturę Чexu otwiera panegiryczna niemal charakterystyka, która kończy się jednakże przekornym stwierdzeniem:

Нет на свете человека деликатнее и воспитаннее чеха...

Он ласков. Он заботлив. Он внимателен. Невозмутим. Всегда прекрасное расположение духа. Исключительно любит нас, русских.

Я никогда не видел, чтобы чех в обществе вышел из себя. А для меня нет ничего приятнее, как взвалить на свои плечи самую трудную задачу в мире. Поэтому я решил вывести чеха из себя... (Averčenko 2018: 128).

Jak się okazało, z równowagi wyprowadzić może mieszkańców Pragi tylko uszczypliwa uwaga o ich ukochanych knedlikach, co bardzo zaskakuje pisarza. Jednakże tak przyjazna praska rzeczywistość przy bliższym poznaniu zaczyna doskwierać rosyjskim emigrantom. Okazuje się bowiem, że Czesi, mimo swej słowiańskiej duszy, znacznie różnią się od Rosjan. Ich zamiłowanie do porządku, poszanowanie prawa i skrupulatne przestrzeganie przepisów regulujących relacje społeczne budzi sprzeciw Rosjan, którzy wszelkie normy i zakazy postrzegają jako ograniczenie ich wolności osobistej. Źródła takiego postępowania kryją się, zda- 
niem Nikołaja Bierdiajewa, w rosyjskim charakterze narodowym, ukształtowanym przez nieogarnione rosyjskie przestrzenie, co nie tylko nie sprzyjało wypracowaniu w Rosjanach samodyscypliny i inicjatywy, lecz także zrodziło ich niechęć do zorganizowanego przypisywania wszystkiego do wyznaczonego mu miejsca, co leży u podstaw zachodnioeuropejskiego mieszczaństwa (Kiejzik 194-195).

Na zakończenie raz jeszcze podkreślmy, że przeobrażenia w rosyjskiej literaturze satyrycznej uwarunkowane trudną sytuacją emigracyjną znalazły także swoje odzwierciedlenie w twórczości Awierczenki. W miniaturach powstałych na wychodźstwie pisarz zawarł bowiem swoje obserwacje dotyczące problemów i dylematów, z jakimi zmagali się jego rodacy na obczyźnie. Towarzyszące emigrantom nieustanne poczucie bezdomności, osamotnienia i wykorzenienia nasilało potrzebę samoidentyfikacji w obcej kulturze, co przejawiało się w manifestowaniu swojej odrębności narodowej, konfrontowaniu z nowymi obyczajami i idealizowaniu przeszłości. Taka postawa bywała jednak nierzadko źródłem sytuacji tyle zabawnych, ile tragicznych, ponieważ na obczyźnie niektóre cechy rosyjskiego charakteru narodowego stawały się szczególnie widoczne.

W utworach napisanych po opuszczeniu kraju Awierczenko nie tylko utrwalał nastroje, życie duchowe i warunki bytowe oraz swoistą metamorfozę rosyjskich emigrantów, lecz także ukazywał ich śmiesznostki, chętnie łącząc pierwiastki komizmu i tragizmu. Dlatego też w miniaturach prozaika okresu emigracji obok humorystycznych scen i zabawnych gier językowych zagościły na stałe autoironia i gorzka refleksja, a czytelników nie dziwiły takie lub podobne słowa, wieńczące miniaturę Русское искусство, pełne tęsknoty za utraconym życiem i jednocześnie lęku przed tym, co przyniesie przyszłość:

\begin{abstract}
А мы сидели трое - кухарка, швейцар и я - и, сблизив головы, тихо говорили о том, что еще так недавно сверкало, звенело и искрилось, что блистало, как молодой снег на солнце, что переливалось всеми цветами радуги и что теперь залилось океаном топкой грязи. Усталые, затуманенные слезами глаза тщетно сверлят завесу мглы, повешенную Господом Богом... Какая это мгла? Предрассветная? Или это сумерки, за которыми идут ночь, одиночество и отчаяние? (Averčenko 2018: 37)
\end{abstract}

\title{
Bibliografia
}

Averčenko, Arkadij. Rasskazy cinika. Moskva, Izdatel'stvo Dmitrij Sečin, 2015.

Averčenko, Arkadij. Zapiski Prostodušnogo. Moskva, T8RUGRAM, 2018.

Averin, Boris Valentinovič, Nikolaj Aleksandrovič Karpov, Svetlana Dmitrievna Titarenko, red. Literatura russkogo zarubež'â (1920-1940). Sankt Peterburg, Filologičeskij fakul'tet SPBGU, 2013.

Błuszkowski, Jan. Stereotypy a tożsamość narodowa. Warszawa, Dom Wydawniczy Elipsa, 2005.

Bondareva, Alena. „Ave - čelovek smeûŝijsâ!”. Russkoe zarubeže'. Velikie sootečestvenniki. 100 sudeb russkoj èmigracii v XX veke. Red. Nikolaj Aleksandrovič Aničkin. Moskva, Âuza - katalog, 2018, s. $13-17$. 
Egorova, Nataliâ Sergeevna. „Tvorčestvo A. T. Averčenko v češskom literaturovedenii”. Vestnik $T G U, \operatorname{nr} 5$ (121), 2013, s. 138-144.

Figes, Orlando. Taniec Nataszy. Z dziejów kultury rosyjskiej. Przeł. Władysław Jeżewski. Warszawa, Wydawnictwo Magnum, 2011.

Ikitân, Lûdmila Nodarievna. „Komičeskie èffekty v povesti A. T. Averčenko Podhodcev $i$ dvoe drugih". Gumanitarnaâ paradigma, nr 1 (8), 2019, s. 54-69.

Ippolitov, Sergej Sergeevič, Sergej Vladimirovič Karpenko, Efim Iosifovič Pivovar. Rossijskâ̂ èmigraciâ v Konstantinopole v načale 1920-h godov. Web. 04.09.2019. http://www.fedy-diary.ru/ library-pages/auditorium-n-f-bugaj-20-50-e-gody-pereseleniya-i-deportacii-evrejskogo-naseleniya-v-sssr/s-s-ippolitov-s-v-karpenko-e-i-pivovar-rossijskaya-emigraciya-v-konstantinopole-v-nachale-1920-x-godov/.

Kasack, Wolfgang. Leksykon literatury rosyjskiej XX wieku. Od poczatku stulecia do roku 1916. Przeł. Bronisław Kodzis. Wrocław-Warszawa-Kraków, Zakład Narodowy im. Ossolińskich, 1996.

Kiejzik, Lilianna, red. Niemarksistowska filozofia rosyjska. Antologia tekstów filozoficznych XIX i pierwszej połowy XX wieku. Część pierwsza. Łódź, Ibidem, 2001.

Kruk, Mikołaj. „Listy satyryczne Arkadiusza Awierczenki”. Satyra w literaturach wschodniosłowiańskich III. Red. Wanda Supa. Białystok, Wydawnictwo Uniwersytetu w Białymstoku, 1999.

Letka-Spychała, Olga. „Obraz «człowieka prostodusznego» w twórczości Arkadija Awierczenki". Twórczość rosyjskiej zagranicy - satyra i memuarystyka. Red. Tatiana Marczenko, Iwona Anna Ndiaye, Dmitrij Nikołajew. Olsztyn, Instytut Słowiańszczyzny Wschodniej UWM, 2018, s. 49-56.

Milenko, Viktoriâ Dmitrievna. „A. T. Averčenko v Belgrade: novye fakty i neizvestnye teksty”. Gumanitarnaâ paradigma, nr 3 (6), 2018a, s. 77-89.

Milenko, Viktoriâ Dmitrievna. „Nečto vrode lekcii o ûmore: neizvestnaâ rukopis' A. T. Averčenko”. Gumanitarnaâ paradigma, $\mathrm{nr} 4$ (7), 2018b, s. 48-63.

Mânovska, Ioanna. „Parodijnyj pereskaz Don-Aminado ob èmigracii i èmigrantah”. Studia Rossica Posnaniensia, nr 39, 2014, s. 219-229.

Nikolaev, Dmitrij Dmitrievič. „Rasskaz A. T. Averčenko Bez počvy i žurnal «Sketing-ring»: poètika i kontekst". Gumanitarnaâ paradigma, nr 1 (8), 2019, s. 18-31.

Sabennikova, Irina Vâčeslavovna. Rossijskaâ èmigraciâ (1917-1939): sravnitel'no-tipologičeskoe issledovanie. Moskva-Berlin, Direkt-Mediâ, 2015.

Škarovskij, Mihail Vital'evič. „Cerkovnaâ žizn' russkih emigrantov v rajone Konstantinopolâ i na Lemnose v načale 1920-h gg.”. Web. 04.09.2019. https://radonezh.ru/analytics/tserkovnaya-zhizn-russkikh-emigrantov-v-rayone-konstantinopolya-i-na-lemnose-v-nachale-1920-kh-gg-46606.html.

Spiridonova, Lidiâ Alekseevna. „Averčenko Arkadij Timofeevič”. Russkoe zarubež'e. Zolotaâ kniga èmigracii. Pervaâ tret' XX veka. Ènciklopedičeskij biografičeskij slovar'. Red. Valentin Valentinovič Šelohaev. Moskva, ROSSPÈN, 1997. Web. 26.09.2019. https://lib.druzya.org/enciklopedia/.view-emigrate.txt.full.html.

Šubin, Roman. „Obraz duraka v tvorčestve V. M. Šukšina”. Rosja w dialogu kultur. T. 2. Red. Bożena Żejmo. Toruń, Wydawnictwo Naukowe Uniwersytetu Mikołaja Kopernika, 2015, s. 443-454.

Tolstoj, Ivan. „Zametki o russkoj Prage”. Novyj Žurnal, nr 251, 2008. Web. 06.09.2019. https:// magazines.gorky.media/nj/2008/251/zametki-o-russkoj-prage.html.

Želtova, Nataliâ Ûrievna. „Poètika russkogo nacional'nogo haraktera $\mathrm{v}$ èmigrantskoj proze A. T. Averčenko". Vestnik TGU, nr 8 (124), 2013, s. 205-209. 